\title{
Se Chico Buarque numa noite de inverno... Apologia do plágio em Budapeste
}

\author{
I If on a Winter's Night Chico Buarque... Apology for plagiarism in "Budapest"
}

\section{Luca Bacchini ${ }^{\mathrm{I}}$}

RESUMO - A obra de Chico Buarque, considerada em todas as variedades de suas expressões, revela desde sempre a peculiar capacidade de tecer um intenso diálogo com as obras de outros autores. Obviamente, dependendo da perspectiva crítica, tal característica pode ser enaltecida como admirável vocação à intertextualidade ou, pelo contrário, estigmatizada como desdenhável propensão ao plágio. A partir de uma leitura comparada entre o seu terceiro romance, Budapeste (2006), e Se um viajante numa noite de inverno (I979), de Italo Calvino, pretendo propor uma reflexão sobre a ideia de plágio, evidenciando como o diálogo descontrolado e imprevisível entre livros, escritores e leitores seja um dos recursos mais preciosos e misteriosos da literatura. - PALAVRAS-CHAVE - Chico Buarque, Budapeste, plágio, Italo Calvino • ABSTRACT • The work of Chico Buarque, considered in the extraordinary variety of its expression, reveals since the beginning a peculiar ability to weave an intense dialogue with the works of other authors. Depending on the critical perspective employed, this feature can be praised as an admirable vocation to intertextuality, or stigmatized as a regrettable tendency to plagiarism. Through a comparative reading of Chico Buarque's third novel, Budapest (2006), and Italo Calvino's If on a Winter's Night a Traveller (I979), the essay proposes a reflection on the idea of plagiarism highlighting how the uncontrolled and unpredictable dialogue between books, writers and readers is one of the most precious and mysterious resources for literature. - KEYWORDS - Chico Buarque, Budapest, plagiarism, Italo Calvino

Recebido em I4 de janeiro de 2016

Aprovado em I4 de janeiro de 2016

BACCHINI, Luca. Se Chico Buarque numa noite de inverno... Apologia do plágio em Budapeste. Revista do Instituto de Estudos Brasileiros, Brasil, n. 63, abr. 2016

DOI: http://dx.doi.org/Io.II606/issn.23I6-90IX.voi63pI7-4I

I Universidade de Bologna, Itália. 
Moral: existem ideias obsessivas,

nunca são pessoais, os livros falam

entre eles, e uma verdadeira

investigação policial deve provar

que os culpados somos nós.

Umberto Eco

A estreia de Chico Buarque na literatura foi marcada pela acusação mais infamante que um escritor pode receber: o plágio. No coro de elogios e apreciação que, merecidamente, acompanhou o lançamento de Estorvo (I99I), foi possível ouvir poucas vozes dissonantes. Entre elas, algumas apontavam para a escassa qualidade narrativa da obra, outras para a falta de originalidade. O jornalista Caio Túlio Costa foi o primeiro a instilar a suspeita do plágio, sinalizando uma filiação entre o romance e a tentativa francesa de recuperar o nouveau roman. Na parte final de uma acirrada invectiva contra o excesso de complacência ("babação de ovo") da crítica em relação ao Chico Buarque escritor, Costa traçava um perfil bem definido do objeto plagiado, afirmando que Estorvo, longe de representar uma novidade na literatura brasileira, seria nada mais que um "decalque de estilo de novelas como 'La salle de bain' (já traduzida no Brasil), do belga Jean-Philippe Toussaint”2. O consenso obtido entre a crítica seria somente a demonstração do escasso conhecimento da literatura estrangeira no Brasil.

Provavelmente por ter sido publicada na coluna do ombudsman, essa denúncia passou quase despercebida. Mas a teoria do plágio estava apenas no início de sua formulação e, em breve, voltou a ser reproposta. O paladino mais aguerrido da

2 COSTA, Caio Túlio. Sobre dessintonias e sintonização. Folha de S.Paulo, Ombudsman, Primeiro Caderno, II ago. I99I, p. Io. 
cruzada a favor da justiça literária foi, sem dúvida, o professor e crítico Wilson Martins, que das páginas de importantes jornais e revistas moveu repetidos ataques com tons cada vez mais irreverentes. Em suas considerações nota-se, desde o início, que a deslegitimação do escritor não precisa da análise dos romances. Todas as acusações lançadas por Martins decorrem da ideia de que haja uma prática do plágio já consolidada na obra musical e teatral de Chico Buarque. Uma vez posta essa premissa, consequentemente a literatura seria apenas um novo campo expressivo no qual o compositor saqueador continuaria a sua atividade habitual.

A primeira denúncia de plagiarismo movida por Martins foi publicada em uma entrevista realizada mais de um ano após o lançamento de Estorvo. Ao refletir sobre o panorama contemporâneo das letras nacionais, as avaliações mais severas eram reservadas para Chico Buarque:

Ele se deixa influenciar pelas obras importantes que leu e escreve paráfrases dessas obras. Para a maioria do público que não conhece as obras originais ele parece melhor do que é na realidade. É o caso de Estorvo, que parafraseia Zero, do Ignácio de Loyola Brandão, mas está longe de ter a mesma qualidade literária³.

Também nesse caso, o sucesso do romance é atribuído à falta de bases literárias dos leitores que aplaudem uma cópia malfeita por não conhecer o modelo original. Pouco mais tarde, com a publicação de Benjamim (I996), a interpretação de Wilson Martins se faz mais contundente ampliando os confins da teoria do plágio. A ofensiva atinge de novo Estorvo e retrospectivamente a peça Fazenda modelo (I974), tendo sempre como alvo principal a deslegitimação do escritor Chico Buarque. Dessa vez, a resenha da última criação literária até dispensa da leitura, pois Benjamim nem é considerado digno de uma reflexão. À luz de uma suposta linha de continuidade entre os roubos dos anos I970 e os mais recentes, o plágio seria já um fato estabelecido e, então, aos estudiosos de literatura caberia apenas a tarefa de identificar a matriz de onde Chico tirou a sua cópia:

Fazenda modelo é apenas um recozimento de Family farm [sic], de George Orwell. Estorvo, por sua vez, é o recozimento de Zero, de Ignácio de Loyola Brandão, que aliás é um livro bem mais interessante. A relação entre Estorvo e Zero é tão escandalosa que me espanta como, na época do lançamento de Estorvo, nenhum resenhista tenha a ela se referido. É a mesma temática e, muitas vezes, apresenta os mesmos episódios. Chico Buarque é um grande músico, mas como escritor é apenas um autor de segundo cozimento. Ainda não li Benjamim, mas estou curioso para ver de onde ele o tirou. Não creio, sinceramente, que Chico Buarque tenha muito futuro como escritor 4 .

Daí a pouco Martins iria satisfazer a própria curiosidade identificando as fontes originárias de Benjamim no modelo do nouveau roman francês e em Cem anos de

3 Wilson Martins, entrevistado por Marleth Silva. A literatura parou. Veja, 4 nov. I992.

4 Wilson Martins, entrevistado por José Castelo. Wilson Martins [palavra ilegível] com coragem. O Estado de São Paulo, 27 jan. I996. 
solidão, de Gabriel García Márquez5 . Naturalmente tais comentários suscitaram muito clamor, sobretudo por vir de um estudioso internacionalmente respeitado. Por um lado, acusavam Chico Buarque de plágio, por outro, o rotulavam como um "literato amador”. O resultado foi uma polêmica, tão áspera quanto inútil, que envolveu o suposto plagiário, seu editor, alguns dos supostos plagiados e uma turma cada vez mais variada de acusadores e defensores ${ }^{6}$. Embora a reação possa aparecer excessiva, a história da literatura ensina que as consequências não podiam ser outras.

Parece que nada há de mais escandaloso e de menos inusitado do que acusar um escritor de plágio. É uma das formas de roubo mais vis e desprezíveis, porque se saqueia, na alma dos outros, para furtar o que há de mais íntimo: as ideias. Basta observar a etimologia da palavra para compreender a gravidade dessa ladroagem imaterial. Plágio vem do grego $\pi \lambda \alpha \gamma$ ios, que significa "ambíguo", "esperto", "embusteiro". No direito romano, plagium indicava o "roubo de homens", e plagiarius era "quem roubava os escravos dos outros ou quem mantinha em cativeiro um homem livre". A primeira codificação do significado moderno encontra-se no início do século XVI no Dictionarium Latinum, de Ambrogio Calepio, em que plagiarius era "quem rouba os livros e os mantém em cativeiros como seus escravos". Enfim, o plagiário é um ladrão e também um escravocrata, pois as ideias não são simples objetos, mas matérias vivas.

Com diversas modalidades, o fantasma do plágio atravessa a literatura desde suas origens. Um dos primeiros testemunhos remonta à comédia ática. Já em 423 a.C., na parábase de $A$ bilha, Crátinos acusava Aristófanes de ser "um que dizia as coisas de Eupólide”, ou seja, de ser um plagiário de Eupólide, o maestro deles7. Perante a secular passarela de plagiários e plagiados, surpreende que o plágio ainda não tenha recebido a devida atenção pela crítica, apesar de ser um dos produtos mais longevos da literatura.

Nesse sentido, Rapport de police (20I0), de Marie Darrieussecq, é umas das poucas e preciosas exceções. Depois de ter sido alvo de repetidas denúncias de roubos

5 MARTINS, Wilson. A imprecisão da literatura de amadores. O Globo, Prosa e Verso, Io fev. I996.

6 A polêmica foi tão vasta a ponto de ocupar a primeira página do suplemento Segundo Caderno na edição de O Globo de I3 de fevereiro de I996. PAVLOVA, Adriana; SUKMAN, Hugo. Ataque a amadorismo na literatura divide escritores. O Globo, Segundo Caderno, I3 fev. I996. Logo depois, sempre nas páginas de O Globo, o editor Luiz Schwarcz publicava uma longa réplica às acusações de Wilson Martins. SCHWARCZ, Luiz. O leitor é um amador por natureza, O Globo, Prosa e Verso, I7 fev. I996. Na polêmica não faltaram as cartas dos leitores, como aquela escrita por Rosa Castro, do Rio de Janeiro, em defesa de Wilson Martins. Cartas, O Globo, Segundo Caderno, I7 fev. I996. Quatro anos mais tarde, Chico Buarque assim comentou numa entrevista: "Wilson Martins, do qual eu disse e repito: um sujeito intelectualmente corrupto. Quando saiu o Estorvo, ele disse na revista Veja que o livro era plagiado do Zero, do Inácio de Loyola Brandão. Isso é facilmente desmentível. Quando saiu o Benjamim, ele foi e deu outra entrevista nas páginas amarelas, dizendo que era um plágio do nouveau roman. Eu nunca li nouveau roman". Chico Buarque entrevistado por Ziraldo, Miguel Paiva, Luís Pimentel, Caco Xavier, Maria Lucia Rangel, Ricardo Leite, Aroeira, Arthur Poerner e Zezé Sacks. Chico Buarque de Hollanda, o homem que não gosta de ouvir música. Bundas, I9 jun. 2000.

7 SONNINO, Maurizio. L'accusa di plagio nella commedia attica antica. In: GIGLIUCCI, Roberto. Furto e plagio nella letteratura del classicismo. Roma: Bulzoni, 1998. 
literários, a romancista francesa passou a pesquisar com cunho crítico o fenômeno do plágio na literatura, escrevendo uma das análises mais aprofundadas sobre o assunto. Dos casos célebres examinados no livro emergem algumas características recorrentes: as acusações de plágio raramente têm fundamentos, são esquecidas rapidamente, mas criam muito escândalo no momento em que são lançadas; o plagiário é quase sempre famoso e é denunciado por alguém (não necessariamente o plagiado) que o percebe como uma ameaça, um inimigo ou um adversário; existe a categoria imprescindível dos “caçadores de plagiários", fiéis defensores da justiça literária que, embora não sejam escritores, querem salvar os escritores verdadeiros vítimas dos escritores falsos. Portanto, a acusação de plágio é a mais poderosa arma de controle da literatura e, mesmo quando inconsistente, pode provocar efeitos graves no acusado, da paralisia da escrita à loucura, da depressão até a morte ${ }^{8}$.

Não foram nenhuma dessas, como sabemos, as consequências para a carreira literária de Chico Buarque, que durante os anos desmentiu amplamente o feral vaticínio de não ter "muito futuro como escritor". É evidente que nos comentários de Wilson Martins, assim como em outras acusações de plágio, a lucidez da análise perca para um mal disfarçado rancor pessoal, o mesmo que o levaria a definir Benjamim como "o romancinho daquele menino, filho de Sérgio Buarque". Mas, apesar de suas intenções deslegitimadoras, cabe reconhecer ao crítico o mérito de destacar em Chico Buarque a capacidade de tecer um intenso diálogo com as obras de outros autores. Obviamente, dependendo da perspectiva, tal característica pode ser estigmatizada como desdenhável propensão ao plágio ou, pelo contrário, enaltecida como admirável vocação à intertextualidade. Sem hesitação, Wilson Martins escolheu a primeira opção e lançou suas denúncias contra os que considerava furtos literários: Fazenda modelo seria um "recozimento" de Animal farm; Estorvo, uma cópia mal-acabada de Zero; e Benjamim, uma bricolagem entre o nouveau roman e Cem anos de solidão ${ }^{\text {To }}$.

Se com espírito de provocação assumirmos essa postura interpretativa, não será difícil identificar os muitos outros "roubos" que Chico Buarque teria perpetrado durante décadas em vários campos da arte: Gota d'água seria um plágio inconteste da Medeia de Eurípides; Ópera do malandro, da Ópera dos mendigos de John Gay e da Ópera dos três vinténs de Bertold Brecht; "Doze anos”, de "Meus oitos anos" de Casimiro de Abreu; "Sabiá", da "Canção do exílio" de Gonçalves Dias; "Até o fim”, do "Poema

8 DARRIEUSSECQ, Marie. Rapport de police. Paris: Folio, 20Io. Ver especialmente as páginas I6-26, 6I-64 e I37-I63. Na escassa bibliografia sobre o tema do plágio, vale a pena destacar o estudo de MASCHERONI, Luigi. Elogio del plagio. Storia, tra scandali e processi, della sottile arte di copiare da Marziale al web. Turim: Aragno, 20I5. Outra obra referencial é The Little Book of Plagiarism (Nova York: Pantheon Books, 2007), de Richard Posner, embora o enfoque principal esteja nas questões de ordem jurídica entre o plagiado e o plagiário. No âmbito da crítica brasileira, merece menção especial o breve mas arguto ensaio "Plágios e plagiários" de Sérgio Buarque de Holanda, publicado em setembro de I92I na Revista do Brasil (VI, 69, vol. XVIII) e mais tarde incluso na coleção O espírito e a letra. Estudos de crítica literária: vol. I (I920-I947), organizada por Antonio Arnoni Prado (São Paulo: Companhia das letras, 2005, p. п16-I30).

9 Wilson Martins, entrevistado por Norma Couri. O Estado de São Paulo, s.d. Disponível em: <http://goo.gl/ ujP4qW >. Acesso em: mar. 2016.

Io MARTINS, Wilson. A imprecisão da literatura de amadores. O Globo, Io fev. I996. 
de sete faces" de Carlos Drummond de Andrade; "Imagina", do verbete "Lua Cris", do Dicionário do folclore brasileiro de Luís da Câmara Cascudo; "Cálice", do Evangelho de Lucas; Leite derramado, de Memórias póstumas de Brás Cubas de Machado de Assis e assim por diante. Continuando a caçada além de Chico Buarque, flagraremos casos até mais escandalosos em todas as artes, especialmente na literatura: ao escrever Ulisses, Joyce teria roubado da Odisseia; O guarani, de Alencar, seria uma reprodução de $O$ último dos moicanos, de Fenimore Cooper; Shakespeare teria copiado de Vidas paralelas, de Plutarco, no Júlio César e no António e Cleópatra; Os contos de Canterbury de Geoffrey Chaucer seriam um decalque do Decamerão de Boccaccio.

As nossas inquisições nos levariam rapidamente a ceifar vítimas entre as obras-primas da narrativa mundial até nos convencermos de que, como afirmava o poeta Josep Pla, a boa literatura é sempre um plágio. De resto, uma ciência inexata como a literatura serve principalmente para revelar o valor dos paradoxos e a importância das dúvidas. Entende-se, portanto, que a única defesa possível da acusação de plágio não é a sua negação, mas a defesa da ideia de plágio, sua admissão, exaltação e legitimação, assim como ensina brilhantemente Mário de Andrade quando replica às acusações de ter roubado o seu Macunaíma da obra de um naturalista alemão - "Copiei sim [...]. O que me espanta e acho sublime de bondade é os maldizentes se esquecerem de tudo quanto sabem, restringindo a minha cópia a Koch-Gruenberg, quando copiei todos"ז.

Afinal, toda a literatura (não só a boa, mas sobretudo a boa) parece fundar-se desde sempre na intertextualidade. "Os livros falam sempre de outros livros e cada história conta outra história que já foi contada”, pontua Umberto Eco ao refletir sobre a sua experiência de escritor ${ }^{\mathrm{I2}}$. Desde as origens, a missão dos estudiosos de literatura comparada foi justamente a de interrogar as fronteiras e as modalidades dessas relações entre os textos, sem o interesse obsessivo em desmascarar furtos ou perseguir plagiários.

Voltando a Chico Buarque, podemos afirmar que, no âmbito de sua produção literária, Budapeste (2003) é o romance que com mais vigor manifesta uma vocação

II ANDRADE, Mário de. Carta a Raimundo Moraes. Publicada no Diário Nacional de São Paulo, em 20 de setembro de I93I. In: Macunaíma. Complemento à edição. Rio de Janeiro: Nova Fronteira, 20I5, p. 202.

I2 ECO, Umberto. Postille a "Il nome della rosa". In: . Il nome della rosa. 3. ed. Milão: Bompiani, 2004, p. 5I3. Tradução minha. Enfim, o plagiador de hoje será o plagiado de amanhã, num fluir incessante de furtos e apropriações indevidas, o que, todavia, não é uma exclusividade da literatura. Na canção "Rubato", por exemplo, Chico Buarque oferece uma representação emblemática da ciclicidade do processo criativo na música. Um compositor chama a mulher amada para ouvir a canção que ele roubou de outro compositor, exortando que venha às pressas, antes que outro compositor ainda, por sua vez, a roube. Porém, cada vez que o refrão é repetido, os versos apresentam pequenas mudanças, inclusive do nome da musa inspiradora (Aurora, Amora e Teodora), provando que, de fato, o roubo já está ocorrendo no momento da execução. BUARQUE, Chico. Rubato. [Autor da letra: Chico Buarque/ Autor da música: Jorge Helder]. Chico Buarque. Biscoito Fino, 20II. I CD, faixa 2.

Para uma síntese histórico-conceitual da ideia de intertextualidade, ver ALLEN, Graham. Intertextuality. Londres/Nova York: Routledge, 2000. 
intertextual ${ }^{\mathrm{T} 3}$. Um primeiro sinal que confirmaria essa característica é a extrema variedade de paralelos e semelhanças proposta pela crítica. Vejamos alguns exemplos. Beatriz Resende propõe comparações com as Ficções de Jorge Luis Borges, os relatos de Júlio Cortázar e "O homem que sabia javanês" de Lima Barreto. José Miguel Wisnik também encontra ecos de Borges (mas o modelo indicado é "Borges e eu" de $O$ fazedor) e de Cortázar (“Lejana”) e, enfim, acrescenta uma referência a "A vida privada", de Henry James. Luís Antônio Giron identifica a fonte oculta do romance na biografia do tradutor húngaro Paulo Rónai, intitulada Como aprendi português e outras aventuras, e define Chico Buarque como o "Rimbaud do samba" e a personagem de José Costa como "um parente sensual de Bartleby”. Luís Chagas considera José Costa inspirado nos romances de Philip Roth e de Rubem Fonseca. Nelson Ascher realça analogias com os romances húngaros da primeira metade do século XX, aproximando Chico a escritores como Gyula Krúdy e Dezsó Kosztolányi. Andréia Delmaschio detecta influências kafkianas e elabora um confronto com A curiosa história do editor partido ao meio na era dos robôs escritores, de José Luis Saorín ${ }^{\mathrm{I}}$.

Então, como explicar a presença na mesma obra de um número tão alto de intertextos diferentes por gêneros, épocas e nacionalidades? Fugindo de uma leitura unilateral, mas aceitando todas as propostas ao mesmo tempo, é possível, na minha opinião, imaginar o perfil de um intertexto mais amplo dentro do qual convergem muitos outros intertextos, até aqueles que a crítica não detectou. Um intertexto atravessado por numerosos - potencialmente infinitos - intertextos, em um jogo ilimitado de referências em que a figura do autor acaba quase se dissolvendo e o leitor é obrigado a seguir o fio de uma narrativa que progressivamente se dispersa em outros textos.

Se um viajante numa noite de inverno (I979), de Italo Calvino, é sem dúvida o exemplo mais eficaz e ambicioso desse modelo narrativo ${ }^{\mathrm{I}}$. Uma obra decisiva para a evolução do romance contemporâneo, fruto de um meditado e descarado "recozimento", escrita, como confessou o seu autor, para "evidenciar o fato de que

I3 BUARQUE, Chico. Budapeste. São Paulo: Companhia das letras, 2003. Todas as citações do romance (B.) serão indicadas diretamente no corpo do texto.

I4 RESENDE, Beatriz. Livro dentro de livro. Jornal do Brasil, I4 set. 2003. WISNIK, José Miguel. Novo romance de Chico Buarque. O Globo, I4 set. 2003. GIRON, Luís Antônio. Com o diabo na língua. Época, I5 set. 2003. CHAGAS, Luís. Estilo retocado. IstoÉ, I7 set. 2003. ASCHER, Nelson. Chico tem uma história e sabe como contá-la. Folha de S.Paulo, I4 set. 2003. DELMASCHIO, Andréia. A máquina de escrita (de) Chico Buarque. Rio de Janeiro: 7Letras, 20I4, n. I7, p. I55 e n. I, p. I34-I35. Surpreendentemente, no caso de Budapeste, houve muitas interpretações em chave comparatista, mas nenhuma acusação de plágio.

I5 "Com Calvino [...] torna-se claro que uma literatura como jogo não podia ter mais nada a ver com uma literatura como transgressão. Calvino é o autor que provavelmente representou melhor os anos nos quais a nossa fé literária mudou”. BERARDINELLI, Alfonso. Calvino moralista, ovvero restare sani dopo la fine del mondo. Diario, n. 7, I99I, p. 48-49. Tradução minha. Para uma visão geral da importância de Se um viajante numa noite de inverno na literatura contemporânea e, em particular, no romance pós-moderno, ver: CESERANI, Remo. Raccontare il postmoderno. Turim: Bollati Boringhieri, I997, p. I66-I80. 
todo o livro nasce na presença de outros livros, em relação e em confronto com outros livros" ${ }^{\circ 6}$.

\section{ERMES E José}

No romance de Calvino, ao longo da intrincada sequência dos dez romances que o Leitor começa sem nunca conseguir terminar, emerge a figura de Ermes Manara, o Grande Mistificador da seita dos falsários de Osaka, que desde sua base secreta na América do Sul confecciona as falsificações dos romances do escritor irlandês Silas Flannery. As afinidades com o protagonista de Budapeste são várias. Sempre na América do Sul, e mais exatamente no Rio de Janeiro, no bairro de Copacabana, encontra-se a sede da agência Cunha \& Costa, onde trabalha um outro célebre ghost-writer, José Costa, membro da prestigiada associação internacional dos escritores anônimos. Ermes Manara e José Costa são dois profissionais de enorme talento capazes de produzir inéditos impecáveis de autores de fama mundial. Desde muitos anos Ermes Manara invade o mercado do livro com os best-sellers do escritor irlandês Silas Flannery; José, por sua conta, pode se gabar de ter composto os célebres Tercetos secretos do emérito poeta húngaro Kocsis Ferenc.

É interessante realçar outra analogia: em ambos os casos, as vítimas da falsificação, que serão também seus beneficiários, são dois autores que não conseguem mais escrever. Silas Flannery é um escritor que está em crise há meses. Procura a inspiração espiando metodicamente uma mulher que lê um livro sentada numa espreguiçadeira. Enquanto a olha, a sua imaginação ferve sem controle: enredos e estruturas de possíveis romances se esboçam em sua mente. Porém, cada vez que tenta fixar as ideias no papel branco, elas somem com a mesma rapidez com a qual apareceram. Atormentado pela incapacidade de dar concretude à inspiração, de capturar um pensamento fugaz, de escrever o que está ainda no "mundo não escrito", Silas acaba sucumbindo:

Como eu escreveria bem se não existisse! Se entre a folha branca e a efervescência das palavras e das histórias que tomam forma e se desvanecem sem que ninguém as escreva não se interpusesse o incômodo tabique que é minha pessoa! [...] Vejo que, de um modo ou de outro, continuo a girar em torno da ideia de uma interdependência entre o mundo não escrito e o livro que eu deveria escrever. É por isso que escrever representa para mim uma operação de tal peso que me esmaga. (S., p. I75-I76.)

Um destino análogo foi reservado ao aparente autor dos Tercetos secretos. Também Kocsis Ferenc é um poeta em crise cuja fama sobrevive apenas em virtude dos versos compostos no passado. Quem resolverá resgatá-lo é José, depois de ter assistido à cena do apagar definitivo de sua veia criativa. Um dia Kocsis entra ofegante no gabinete

I6 CALVINO, Italo. Il libro, i libri. Nuovi quaderni italiani, I984. In: Se um viajante numa noite de inverno. Trad. Nilson Moulin. São Paulo: Companhia das Letras, 2009, p. 266, em nota. Todas as citações do romance (S.) serão indicadas diretamente no corpo do texto. 
do Clube das Belas-Letras de Budapeste e lhe pede papel e caneta para escrever seus versos. A inspiração parece finalmente ter voltado. Mas ao encarar o branco da folha, o exímio poeta sofre de novo um repentino bloqueio e se afasta derrotado:

Abriu o caderno, tirou do bolso uma caneta antiquada, desenroscou a tampa com dificuldade, e sua mão tremia, tremia como se escrevesse freneticamente, no ar. Mas nem bem pousou a pena no papel, passou a tremedeira, a mão se imobilizou, palavra nenhuma aconteceu. Olhei o semblante do poeta, vi gotas de suor nos sulcos de sua testa, vi dentes amarelos, pensei que o poeta estivesse rindo, mas era um ricto da sua boca. Depois seus nervos foram se distendendo, seus ombros cederam, seu corpo inteiro afrouxou, a caneta escorregou de sua mão, e com a boca mole Kocsis Ferenc disse: perdi. (B., p. I36.)

Na verdade, considerando as características do autor objeto da operação de ghost-writing, a imprensa literária de José aparece até mais admirável. Pouco sabemos da produção de Kocsis Ferenc, com a exceção do refrão da sua poesia de maior sucesso: egyetlen, érintetlen, lefordíhatatlan (único, puro, intraduzível). Trata-se de três adjetivos que no romance nunca aparecem com a tradução e que, se tivessem valor autorreferencial (se, por exemplo, fossem referidos pelo poeta a si mesmo ou ao seu canto), tornariam os Tercetos secretos uma obra ainda mais extraordinária, capaz de reproduzir um estilo poético que tinha a ousadia de se definir "único", "puro" e "intraduzível": um verdadeiro desafio para o talento de José.

Prosseguindo no cotejo de Silas Flannery com Kocsis Ferenc, observamos que ambos gozam da mal disfarçada admiração das mulheres pelas quais os dois ghost-writers estão respectivamente apaixonados. Por um lado, Ludmilla, a moça amada por Ermes Manara, é uma leitora encantada pelos romances de Flannery. Possui até um exemplar com dedicatória que o escritor irlandês lhe teria dado de presente. Por outro lado, José flagra a esposa Vanda trocando olhares maliciosos com Kocsis Ferenc no consulado húngaro do Rio de Janeiro durante o lançamento dos Tercetos secretos. Mas o destino será cruel com José, pois sucessivamente descobrirá que Kaspar Krabbe, o empresário alemão para o qual tinha escrito sob encomenda a autobiografia, foi bem mais atrevido e abusado de que o afamado poeta húngaro. Um dia, na cesta das revistas da esposa José encontra um exemplar da autobiografia enriquecido por uma dedicatória bastante comprometedora ("para Wanda, lembrança do nosso tête-à-tête, encantado, K.K”. B., p. 80).

O que podemos supor é que, para Ermes Manara e José Costa, ghost-writing equivale a uma espécie de atividade terapêutica projetada para abrandar o ciúme que os atormenta. Ambos provam um prazer perverso ao invadir a relação íntima e de cumplicidade que as mulheres amadas estabelecem com os escritores durante a leitura. Com efeito, foi o ciúme da presença invisível e constante dos muitos - demais - escritores nas leituras de Ludmilla que levou Ermes a transformar-se de tradutor em ghost-writer:

Pouco a pouco você acabará por entender melhor as origens das maquinações do tradutor: a mola secreta que as desencadeou foi o ciúme despertado pelo rival invisível 
que se interpunha continuamente entre ele e Ludmilla, a voz misteriosa que lhe fala através dos livros, esse fantasma sem rosto que tem mil faces e, portanto, é ainda mais fugidio, pois para Ludmilla os autores não se materializam nunca em indivíduos de carne e osso, para ela só existem nas páginas publicadas, vivos ou mortos, lá estão, sempre ali prontos a comunicar-se com ela, a maravilhá-la, a seduzi-la, e Ludmilla sempre pronta a segui-los, com a leviandade das relações com pessoas incorpóreas. (S., p. I63.)

Como eliminar a ameaça de um amante tão esperto e inalcançável? Derrotar todos os escritores da história passada e presente da literatura seria impossível. Ermes compreende que para ganhar a luta não deve focar-se na multidão dos autores, mas na função da autoria. Se tivesse conseguido insinuar constantemente a dúvida da mistificação, ele teria prejudicado para sempre a confiança de quem lê. Assim Ludmilla não poderia mais abandonar-se serenamente às suas leituras, porque atrás de qualquer autor que ela tivesse amado seria possível vislumbrar a sombra de um falsificador:

Ermes Manara - desde sempre, porque seu gosto e talento o impeliam a isso, mais ainda depois que sua relação com Ludmilla entrou em crise - sonhava com uma literatura composta exclusivamente de obras apócrifas, de falsas atribuições, de imitações, contrafações e pastiches. Se essa ideia conseguisse impor-se, se uma incerteza sistemática quanto à identidade de quem escreve impedisse o leitor de abandonar-se com confiança - confiança não tanto no que é contado, mas na voz misteriosa que conta -, talvez nada mudasse no exterior do edifício da literatura... Mas, por baixo, nos alicerces, lá onde se estabelece a relação entre leitor e texto, algo mudaria para sempre. Então Ermes Manara não mais haveria de sentir-se abandonado por Ludmilla quando ela estivesse absorta na leitura: entre o livro e ela sempre se insinuaria a sombra da mistificação, e ele, identificado com cada uma das mistificações, teria confirmada sua presença. (S., p. I63.)

Para José, a falsificação de um texto é uma experiência pessoal que não deve ser absolutamente compartilhada nem com o autor aparente nem com o leitor. Um ghost-writer nunca deve revelar a própria identidade. José não ambiciona invalidar a autoridade de um escritor, nem sequer insinuar a dúvida na mente do leitor. Pelo contrário, ele se gratifica ao apurar a confiança total que ambos põem em sua mistificação. O prazer da mistificação para José não está na afirmação da presença do ghost-writer dentro da obra, mas no prazer de uma postura voyeurística que permite ao ghost-writer acompanhar às escondidas o processo de sedução entre o leitor e o autor. Nada o excita mais de que observar a esposa Vanda que lê inconscientemente um texto dele achando que fosse de outro autor. Assim, quando um artigo escrito por ele era publicado sob falso nome, José espalhava pela casa vários exemplares do jornal na esperança de que Vanda chegasse a lê-lo e que até mostrasse apreciação. Se a mulher ainda tivesse acenado um sorriso durante a leitura, teria sido como espiá-la enquanto se despia: 
Então comprava vários exemplares do jornal e os deixava com meu artigo à mostra no caminho dela, na mesa de jantar, em cima do telefone, no berço do menino, junto ao espelho do banheiro. Ver a Vanda correr os olhos sobre as minhas letras, esboçar um sorriso, apreciar um texto meu sem saber que o era, seria quase como vê-la se despir sem saber que eu a estava olhando. Mas não, ela pegava o jornal e revirava as páginas, olhava umas fotografias, lia as legendas, a Vanda não tinha paciência para grandes leituras. (B., p. Iоз.)

Ver o sucesso de suas criações indevidamente atribuído aos outros não lhe causava alguma frustração. Não se considerava vítima, embora consciente, de uma desapropriação de sua escritura; pelo contrário, sentia a culpa de ter invadido páginas alheias, como se fosse um amante secreto. Essa clandestinidade assumida dentro de uma obra, provoca em José uma sensação bastante confusa, "um tipo de ciúme ao contrário", que o leva a mediar entre a vaidade cada vez maior alimentada pelos sucessos de suas composições e a exigência de proteger o anonimato de sua função:

[...] ver minhas obras assinadas por estranhos me dava um prazer nervoso, um tipo de ciúme ao contrário. Porque para mim, não era o sujeito quem se apossava da minha escrita, era como se eu escrevesse no caderno dele. Anoitecia, e eu tornava a ler os fraseados que sabia de cor, depois repetia em voz alta o nome do tal sujeito, e balançava as pernas e ria à beça no sofá, eu me sentia tendo um caso com mulher alheia. E se me envaideciam os fraseados, bem maior era a vaidade de ser um criador discreto. Não se tratava de orgulho ou soberba, sentimentos naturalmente silenciosos, mas de vaidade mesmo, com desejo de jactância e exibicionismo, o que muito valorizava minha discrição. E novos artigos me eram solicitados, e publicados nos jornais com chamada de capa, e elogiados por leitores no dia seguinte, e eu aguentava firme. (B., p. I7-I8.)

A qualidade e a variedade de sua produção fazem de José um ghost-writer extraordinário. Desde quando começou a trabalhar na agência, escreveu de tudo: dissertações, monografias, provas de medicinas, autobiografias, petições de advogados, cartas de amor, de adeus, discursos de políticos, ameaças de suicídio, chantagens. $\mathrm{O}$ seu talento lhe permite atender às exigências de qualquer tipologia de cliente, encontrando sempre em si um outro Eu em nome do qual se expressar. Todavia, a sua produção não está limitada ao Brasil e à língua portuguesa. Com o tempo adquiriu um domínio da língua húngara tão completo ao ponto de realizar falsificações até do eminente poeta Kocsis Ferenc que, sucessivamente, foram traduzidas em muitos outros países, inclusive na China.

De acordo com o modelo de literatura sonhado por Ermes Manara, as características de José Costa correspondem em pleno ao perfil do "autor ideal". Ermes acredita que os autores que achamos reais não existem, pois, na verdade, seriam personagens inventados pelos autores verdadeiros (que nunca se revelam) para cumprir o papel de autor das ficções que eles escrevem. Em suma, a literatura, para Ermes, vale apenas para o seu poder de mistificação, pois é na mistificação que reside a verdade. O ghost-writer é o "autor ideal" porque, enquanto mistificador de 
uma mistificação, é portador de uma verdade dupla em comparação com os outros escritores:

Pensando bem, esse escritor total poderia ser uma pessoa muito modesta, aquilo que nos Estados Unidos chamam ghost-writer, um escritor-fantasma, um profissional de reconhecida utilidade, embora sem grande prestígio: o redator anônimo que dá forma de livro àquilo que outras pessoas têm para contar, mas que elas não sabem ou não dispõem de tempo para escrever; a mão escritora que dá palavras a existências demasiado ocupadas em existir. (S., p. I85.)

\section{OS DEZ INCIPIT E JOsÉ}

Os pontos de contatos entre Se um viajante numa noite de inverno e Budapeste não se esgotam apenas na semelhança entre os dois ghost-writers, mas envolvem outros aspectos da narração. O tema do imprevisto de viagem, por exemplo, caracteriza o início de ambas as histórias. O primeiro romance do livro de Calvino se abre com a cena de um homem que vagueia pela estação ferroviária com o ar de quem perdeu a conexão ("Meu comportamento exterior é o de um viajante que perdeu uma baldeação”, S., p. 22-23). Analogamente às aventuras de José Costa, começam a partir de uma escala não planejada na capital húngara ("Fui dar em Budapeste graças a um pouso imprevisto, quando voava de Istambul a Frankfurt, com conexão para o Rio”, B., p. 6) ${ }^{\mathrm{I7}}$.

Continuando na comparação, reparamos que a uma reflexão linguística presente no segundo incipit de Se um viajante numa noite de inverno corresponde a cena cômica do primeiro café da manhã de José no hotel de Budapeste. Em "Fora do povoado de Malbork”, aprende-se que em uma remota localidade da Europa Oriental chamada Kudgiwa, na cozinha da residência do senhor Kauderer, há uma mulher robusta, dotada de braços vermelhos e firmes, preparando comida. Guiando o Leitor entre os cheiros que se espalham pela cozinha descrita por Tazio Bazakbal, o Autor reflete sobre a oportunidade de traduzir ou não as palavras que indicam os diferentes pratos. Como pode o Leitor imaginar o sabor de um alimento que nunca experimentou? O sabor de uma comida, cogita o Autor, já está incluído no som da palavra usada para designá-la. A nada serve recorrer a sofismas linguísticos ou a improváveis comparações gastronômicas. A escolha, feita pelo tradutor de Bazakbal, de manter os nomes da comida na língua original não é um obstáculo para o Leitor que, embora

I7 A questão do imprevisto da viagem nos conduz também para o admirável romance Epepe (I970), de Ferenc Karinthy, que, por sua vez, revela impressionantes elementos em comum com Budapeste. Budai é um linguista culto e estimado em viagem para um congresso de linguística em Helsinki. Pega o voo errado e desembarca numa cidade onde se fala um idioma desconhecido. E, como José Costa, de dentro de um quarto de hotel, Budai começa a sua luta por sobrevivência com as palavras ignotas, entre escritas e sons indecifráveis. A única pessoa disponível para confortá-lo é a ascensorista do hotel, uma jovem loira, alta e bonita pela qual acabará se apaixonando. 
impossibilitado de desfrutar de órgãos gustativos, pode igualmente definir os sabores dos pratos presentes no romance através do ouvido:

Aqui tudo é muito concreto, denso, definido com competência garantida, ou pelo menos a impressão que você tem, Leitor, é de competência, embora não conheça certos pratos, cujos nomes o tradutor achou melhor deixar na língua original, schoëblintsjia, por exemplo, mas você, ao ler schoëblintsjia, é capaz de jurar que a schoëblintsjia existe, consegue sentir-lhe distintamente o sabor, mesmo que o texto não mencione nada sobre isso, um sabor acídulo, sugerido um pouco talvez pela sonoridade da palavra, um pouco pela grafia, ou ainda porque, nessa sinfonia de aromas, sabores e palavras, você tem a necessidade de uma nota acidulada. (S., p. 4I.)

Também José Costa está convencido que não seja possível saborear em pleno uma comida sem conhecer o seu nome original. Pensa que as faculdades gustativas estão profundamente influenciadas pelas qualidades fonéticas da palavra que designa o alimento. O primeiro encontro de José com a comida húngara ocorre no hotel do aeroporto de Budapeste, onde fica hospedado por uma noite depois que seu voo é submetido a um pouso forçado por causa de uma ameaça de bomba. De manhã, antes de embarcar para o Brasil, José vai ao restaurante do hotel para tomar o café da manhã. Na mesa onde o colocam encontra uma cesta com algumas broas avermelhadas que, apesar do receio, resolve experimentar. José gosta dessa iguaria húngara, porém a sua experiência gustativa não pode se dizer completa sem ter ouvido o nome dela na língua local. Então, pede mais informações aos garçons que, contrariamente ao tradutor de Bazakbal, acham que o sabor de um prato pode ser explicado através da descrição de sua receita. Mas José reclama o som estrangeiro de uma palavra húngara para que possa degustá-lo com o sabor misterioso das broas de Budapeste:

Restavam intocados na cesta de pães uns similares de broas avermelhadas, na certa uma especialidade nativa, que provei com cautela e por educação. A massa era leve, de um sabor adocicado que com o tempo deixava uma lembrança amargosa. Comi a primeira, a segunda, acabei comendo as quatro porque estava faminto, e a coisa não era de todo ruim, se engolida com chá. Tratava-se de um pão de abóbora, conforme o maître informou em inglês, mas eu não queria a receita da broa, queria saborear seu som em húngaro. In Hungarian, insisti, e desconfiei que eles tinham ciúmes de sua língua, pois o maître não se deu por achado; fez um ô gutural, despejou no meu prato um monte de broas, rejeitadas pelas mesas vizinhas, e bateu as mãos para me apressar, fazendo ver que o restaurante estava vazio. (B., p. Io-II.)

Outras vezes o diálogo intertextual se faz ainda mais complexo, envolvendo ao mesmo tempo elementos diferentes. Numa das cenas mais belas de Budapeste é possível imaginar pontos de contatos não somente com a história de Ermes Manara e do diário de Silas Flannery, mas também com a aventura amorosa do Leitor e da Leitora. José Costa acaba de voltar ao Brasil depois de ter passado um mês na Hungria. Anda pela orla de Ipanema obcecado pela lembrança da esposa Vanda e da amante 
Kriska, duas mulheres que na sua mente se tornam quase especulares e que, durante a caminhada, afloram na fisionomia e na postura das mulheres que lhe passam ao lado. José tem a impressão de ter visto a esposa de canga e chapéu de palha, mas, em um instante, cogita que seja Vanessa, a prima dela. A mesma dúvida retorna diante de uma moça sentada de frente para o mar:

[...] no final da praia, a reconheci de novo noutra moça, não pela andadura, mas exatamente pela forma de estar imóvel, sentada num banco de frente para o mar. Eu sabia muito bem que a Vanda estava em São Paulo, mas ainda pensei, é a Vanessa, que também tinha esse modo de dobrar ambas as pernas para um lado, como a guardar o lugar para outra pessoa, talvez um cacoete de gêmeos. Claro que não era a Vanessa, era pouco mais que uma menina, e só ao parar às suas costas lhe notei um sinal de vida, um suave e espaçado alçar de ombros, sua lenta respiração. Já estava convencido de que era uma iogue, quando me assustou o gesto abrupto de sua mão esquerda. Olhei por cima de sua cabeça, e ela acabava de virar a folha de um livro. Só então percebi que estava lendo, e o que tinha no colo parecia o meu livro. Sentei-me na ponta do banco ao lado dos seus pés e conferi a capa mostarda de $O$ Ginógrafo, que ela lia com os olhos em ziguezague. Abri também meu exemplar e segui de viés a leitura dela, seus lábios semiabertos, com aparelho nos dentes. Ela virava as folhas com sofreguidão, para não perder o fio da aventura, ou a cadência das minhas frases, e já ia pela metade do livro quando deteve os olhos no alto de uma página ímpar, franziu a testa, pareceu embatucar numa palavra, receei que desistisse da leitura. De fato fechou o livro, marcando-o com um palito de picolé, guardou-o numa cesta de lona, e ao desdobrar as pernas me chutou de leve, pediu desculpas, não me havia visto. (B., p. 95-96.)

Essa moça sentada num banco de frente para o mar revela uma forte semelhança com a jovem mulher ("giovane donna", no original) sentada numa espreguiçadeira que é descrita por Silas Flannery em seu diário:

Numa espreguiçadeira, no terraço de um chalé, no fundo de um vale, há uma mulher que lê. [...] Nesse ar leve e transparente, eu julgo colher em sua figura imóvel os sinais desse movimento invisível que é a leitura, o correr do olhar e da respiração e, mais ainda, o percurso das palavras através de sua pessoa, o fluxo e as interrupções, os impulsos, as hesitações, as pausas, a atenção que se concentra ou se dispersa, os retrocessos, essa trajetória que parece uniforme, mas que é sempre mutante e acidentada. [...] aponto a luneta para controlar o efeito de minha frase em seu olhar, na dobra de seus lábios, no cigarro que ela acende, nos movimentos de seu corpo na espreguiçadeira, nas pernas que se cruzam ou se distendem. (S., p. I73-I74.)

Ambas as moças estão lendo o livro escrito pelo homem que as está espiando Silas imagina até que a frase que ele está para escrever corresponderia àquela que a moça sentada na espreguiçadeira já está lendo. Comum aos dois romances é também a descrição particularizada da mulher enquanto lê: uma figura aparentemente imóvel que, se observada com atenção, revela pequenos movimentos quase imperceptíveis. Tanto Silas quanto José se detêm nos mesmos detalhes do corpo de suas respectivas 
leitoras (os olhos que acompanham as palavras impressas, o ritmo lento da respiração, os lábios semiabertos, as pernas que se esticam). A leitura se apresenta como um processo irregular, feito de pausas repentinas, arranques repentinos, hesitações inesperadas e voltas para atrás que ambos os autores se deliciam acompanhar seguindo cada reação da leitora.

José queria tentar uma abordagem com a leitora. O pretexto que utiliza é aquele desfrutado pelo Leitor com a Leitora, ou seja, o fato de compartilharem o mesmo romance. Quando o Leitor chega a saber pelo livreiro que a moça na loja também tinha comprado por engano o livro do escritor polonês Tazio Bazakbal, imediatamente elabora uma estratégia para quebrar o gelo com ela:

Vamos, não perca tempo, você já tem um bom argumento para iniciar a conversa, um terreno comum, pense um instante, pode exibir suas leituras amplas e variadas, vá em frente, o que está esperando?

-- Então você também, rá-rá, o polonês? - você diz, de uma vez só. -- Mas este livro que começa e se interrompe, que incompetência, disseram-me que com você também, comigo aconteceu a mesma coisa, sabe como é, se é para arriscar, desisti daquele e estou levando este, que grande coincidência nós dois, não? (S., p. 36.)

José também aproveita da questão do livro para se aproximar da leitora sentada no banco. Mas, contrariamente à personagem inventada por Calvino, José não se apresenta como um leitor de $O$ Ginógrafo de Kaspar Krabbe. Contudo, não revela para a moça que ele é o verdadeiro autor do livro. Assim como faria Ermes Manara, José permanece fiel à discrição e à reserva que lhes são impostas pela profissão de ghost-writer. Diz à moça que é um amigo do autor e logo tenta mostrar o seu exemplar assinado, mas, infelizmente, não tem a mesma sorte do Leitor com a Leitora. A mulher some antes que ele termine a sua tentativa de sedução: "Então apontei a capa mostarda em minhas mãos, a coincidência, depois busquei a folha de rosto com a dedicatória, disse que o autor era meu amigo, mas ela já tinha ido embora” (B., p. 96).

\section{O Leitor, a Leitora, Kaspar E Teresa}

A cena do primeiro encontro entre o Leitor e a Leitora revela afinidades com o início da história de José com Kriska. Em Se um viajante numa noite de inverno e em Budapeste a livraria é o lugar onde o futuro casal de amantes se conhece. O Leitor, como já vimos, vai à livraria para trocar o exemplar defeituoso do livro de Calvino e lá o livreiro lhe aponta uma moça, a Leitora, que também incorreu no mesmo imprevisto:

O livreiro já indicou a moça para você. Lá está ela, entre duas estantes da livraria; está procurando entre os Penguin Modern Classics, corre o dedo delicado e resoluto pelas lombadas cor de berinjela clara. Olhos grandes e irrequietos, pele corada e boa, cabelos profusos e vaporosos. (S., p. 35-36.) 
E uma livraria servirá também como cenário para o encontro fatal entre José Costa e a sua futura professora-amante Kriska. Em busca de um abrigo da chuva, José entra numa livraria de Budapeste onde acaba comprando um curso para o estudo da língua húngara. Como a Leitora, José está folheando um livro (Hungarian in Ioo lessons) quando Kriska se aproxima. A mulher, que à primeira vista José confunde com um fiscal da loja, tira o livro de suas mãos e o joga no fundo da prateleira dizendo - conforme o que José imagina ter entendido - que o húngaro não é um idioma que se aprende nos livros:

Cheguei a uma prateleira repleta de grossos volumes, corri os olhos pelos títulos húngaros em seus dorsos e tive a visão de uma biblioteca deveras desorganizada, caótica. Depois observei melhor, e as capas estavam todas alinhadas, as letras é que pareciam fora de ordem. Por isso me chamou a atenção o livro mais modesto, mas com um título legível: Hungarian in Ioo lessons. Numa folheada entrevi alguns exercícios de conversação: este trem vai para a Bulgária?; minha esposa é vegetariana; quanto mede o velho obelisco?; preciso comprar candelabros baratos; onde mora aquele soldado? Então percebi a moça alta com uma mochila nas costas que olhava o livro em minhas mãos e abanava a cabeça. Pensei tratar-se de uma fiscal da casa, e que fosse proibido aos fregueses manusear a mercadoria. De pronto lhe estendi o livro, que ela agadanhou e jogou de qualquer jeito no fundo de uma prateleira. A rispidez do gesto, presumi que fosse uma característica dos hunos, como as maçãs do rosto dela, um tanto salientes, ou os lábios que julguei cruéis, porque sem muita polpa. E quando ela afirmou que a língua magiar não se aprende nos livros, fiquei pasmo, porque a sentença me soou perfeitamente inteligível. (B., p. 59.)

Numa perspectiva comparada, a história do Leitor e da Leitora oferece surpreendentes analogias também com o enredo de $O$ Ginógrafo, ou seja, a autobiografia que o empresário alemão Kaspar Krabbe tinha encomendado a José Costa. O primeiro encontro de amor entre os dois personagens de Calvino é descrito como uma operação de leitura na qual o corpo do outro é lido como se fosse um livro aberto, mas sem seguir um percurso linear:

Leitora, eis que agora você está sendo lida. Seu corpo está sendo submetido a uma leitura sistemática, mediante canais de informação táteis, visuais, olfativos, e não sem intervenções das papilas gustativas. [...] Também você, ó Leitor, é entrementes um objeto de leitura: a Leitora ora lhe passa o corpo em revista como se percorresse o sumário, ora o consulta como se tomada por uma curiosidade rápida e precisa, ora se demora interrogando-o e deixando que uma resposta muda chegue a ela. (S., p. I59.)

O Leitor e a Leitora são ao mesmo tempo sujeito e objeto de uma leitura recíproca que, portanto, só pode ser necessariamente biográfica: "Hoje vocês são cada um o objeto da leitura do outro, cada um lê no outro sua história não escrita” (S., p. I60).

A ideia de poder ler a própria história no corpo do amante será o tema principal de $O$ Ginógrafo, a autobiografia de Kaspar Krabbe. Porém, diferentemente de Italo Calvino, Chico Buarque concentra a sua atenção mais na escritura do que na leitura. 
A palavra "ginógrafo" é um neologismo composto por $\gamma v v \eta$ (mulher) e $\gamma \rho \alpha \varphi \omega$ (escrever), que indica "quem escreve nas mulheres". Diferentemente do Leitor de Calvino, Kaspar Krabbe não "lê no outro a sua história não escrita", mas escreve materialmente a própria história no outro. Essa passagem do plano da leitura para o da escritura determina uma mudança radical dos equilíbrios entre os dois sexos dentro da vida do casal. Da relação paritária entre o Leitor e a Leitora, baseada numa leitura recíproca dos corpos ("vocês são cada um o objeto de leitura do outro"), recuamos para o modelo machista de Kaspar Krabbe, no qual a mulher desenvolve somente a função passiva de ser a superfície para a escritura do homem. As implicações sexuais desse modelo são desenvolvidas com habilidade por Chico Buarque ao longo da construção narrativa. A escritura de Kaspar, assim como a leitura para o Leitor, é uma atividade que une o prazer físico e o deleite intelectual seja para o homem que escreve seja para a mulher que é escrita. Kaspar começa a compor a sua autobiografia no corpo de Teresa, uma mulher encontrada pelas ruas de Rio de Janeiro pouco depois de ter chegado da Alemanha. Inicialmente o amor e a escrita fluem felizes até quando Teresa percebe que Kaspar não está interessado nela, mas apenas em escrever em seu corpo:

A escrita me saía espontânea, num ritmo que não era o meu, e foi na batata da perna de Teresa que escrevi as primeiras palavras na língua nativa. No princípio ela até gostou, ficou lisonjeada quando eu lhe disse que estava escrevendo um livro nela. Depois deu para ter ciúmes, deu para me recusar seu corpo, disse que eu só a procurava a fim de escrever nela, e o livro já ia pelo sétimo capítulo quando ela me abandonou. (B., p. 39.)

Uma vez abandonado, Kaspar não parece estar mais em condição de continuar o livro sem o corpo de Teresa. Tenta escrever numa folha branca e, mais tarde, até em seu próprio corpo, mas sem resultados. Daí o empresário alemão se lança à procura dos corpos de outras mulheres nas quais poder saciar a sede de escritura. Ao contrário do Leitor monógamo de Calvino que nunca trai o amor pela Leitora, aqui o relacionamento do casal desmorona, e Teresa será substituída por outras mulheres. De qualquer maneira, a autobiografia deve continuar. Kaspar, então, se transforma em um irrequieto escritor polígamo, e os últimos capítulos de $O$ Ginógrafo espalham-se pelos corpos das muitas mulheres, ora pagas, ora seduzidas, enquanto Teresa lhe concede apenas o prazer clandestino de um punhado de palavras durante a ausência do marido:

Sem ela, perdi o fio do novelo, voltei ao prefácio, meu conhecimento da língua regrediu, pensei até em largar tudo e ir embora para Hamburgo. Passava os dias catatônico diante de uma folha de papel em branco, eu tinha me viciado em Teresa. Experimentei escrever alguma coisa em mim mesmo, mas não era tão bom, então fui a Copacabana procurar as putas. Pagava para escrever nelas, e talvez lhes pagasse além do devido, pois elas simulavam orgasmos que me roubavam toda a concentração. Toquei na casa de Teresa, estava casada, chorei, ela me deu a mão, permitiu que eu escrevesse umas breves palavras enquanto o marido não vinha. Passei a assediar as estudantes, que às vezes me deixavam escrever nas suas blusas, depois na dobra do braço, onde sentiam 
cócegas, depois na saia, nas coxas. E elas mostravam esses escritos às colegas, que muito os apreciavam, e subiam ao meu apartamento e me pediam que escrevesse o livro na cara delas, no pescoço, depois despiam a blusa e me ofereciam os seios, a barriga e as costas. E davam a ler meus escritos a novas colegas, que subiam ao meu apartamento e me imploravam para arrancar suas calcinhas, e o negro das minhas letras reluzia em suas nádegas rosadas. (B., p. 39-40.)

A leitura, íntima e pessoal, protagonizada pelo casal dos Leitores de Calvino, aqui ganha uma dimensão semipública entre os círculos das estudantes assediadas, produzindo uma eficaz ação de propaganda a benefício de Kaspar Krabbe. Cada vez mais estudantes batiam em sua porta entregando-lhe os corpos e, assim, a redação do Ginógrafo volta a avançar expeditamente. Novos capítulos brotam nos corpos das moças caídas na sua rede sedutora até o dia em que aparece uma mulher, diferente das outras, que lhe ensina a escrever de trás para frente: uma espécie de Penélope, que de noite cancela tudo o que Kaspar tinha escrito nela durante o dia, de modo que a atenção do amante possa se prolongar ao infinito. Essa mulher sem nome, da qual Kaspar se apaixona perdidamente, determinará uma nova transformação na composição da autobiografia. A escrita volta a ser monógama como na época de Teresa, e a leitura se torna um privilégio exclusivo da misteriosa mulher, a única capaz de ler os textos impressos no seu corpo:

Moças entravam e saíam da minha vida, e meu livro se dispersava por aí, cada capítulo a voar para um lado. Foi quando apareceu aquela que se deitou em minha cama e me ensinou a escrever de trás para diante. Zelosa dos meus escritos, só ela os sabia ler, mirando-se no espelho, e de noite apagava o que de dia fora escrito, para que eu jamais cessasse de escrever meu livro nela. E engravidou de mim, e na sua barriga o livro foi ganhando novas formas, e foram dias e noites sem pausa, sem comer um sanduíche, trancado no quartinho da agência, até que eu cunhasse, no limite das forças, a frase final: e a mulher amada, cujo leite eu já sorvera, me fez beber da água com que havia lavado sua blusa. Voltei ao princípio do texto no computador, e a revisão de um livro era para mim um tempo de extremo apego. (B., p. 40.)

A amalgama entre o prazer do corpo e da escritura é sublimado pelo final de O Ginógrafo. Kaspar Krabbe escreve a frase conclusiva da sua autobiografia no ventre grávido da mulher amada, fazendo coincidir o início de uma nova vida com o fim do relato da própria. E, nesse momento do romance, quando o leitor resolve se entregar à narração do empresário alemão, José Costa reivindica improvisadamente a natureza ficcional da autobiografia, reposicionando o cenário da escritura que do corpo da mulher amada por Kaspar passa para a tela do computador da sua agência de falsificações.

Mais tarde descobrimos que a frase que fecha $O$ Ginógrafo é a mesma com a qual termina também Budapeste. E esse jogo intratextual nos leva para outro elemento de convergência com Se um viajante numa noite de inverno. O desfecho do romance de Calvino, como se sabe, representa um dos mais intrigantes happy end da literatura contemporânea: 
Agora vocês são marido e mulher, Leitor e Leitora. Um grande leito matrimonial acolhe suas leituras paralelas. Ludmilla fecha seu respectivo livro, apaga sua respectiva luz, abandona a cabeça no travesseiro e diz:

— Apague você também. Não está cansado de ler?

E você:

- Só mais um instante. Estou quase acabando Se um viajante numa noite de inverno, de Italo Calvino. (S., p. 263.)

Também na conclusão do livro de Chico Buarque o amor acaba triunfando. Como o Leitor e a Leitor, José e Kriska estão deitados numa cama de casal e estão lendo:

Deitou-se de lado na cama e recostou a cabeça em meu ombro, ciente de que, sem interromper a leitura, eu sentia prazer em ver suas ancas realçadas sob a camisola. Então moveu de leve uma perna sobre a outra, deixando nítido o desenho de suas coxas debaixo da seda. E no instante seguinte se encabulou, porque agora eu lia o livro ao mesmo tempo em que o livro acontecia. Querida Kriska, perguntei, sabes que somente por ti noites a fio concebi o livro que ora se encerra? Não sei o que ela pensou, porque fechou os olhos, mas com a cabeça fez que sim. E a mulher amada, de quem eu já sorvera o leite, me deu de beber a água com que havia lavado sua blusa. (B., p. I73.)

Aqui também assistimos a um final construído através da materialização do "livro em ato" ("agora eu lia o livro ao mesmo tempo em que o livro acontecia”, explica José). O Leitor está lendo Se um viajante numa noite de inverno, e José, por sua conta, está lendo um livro que sabemos cujo título ser Budapeste. Em ambos os casos nós, leitores com "l" minúsculo, ficamos atônitos curtindo daquela prazerosa sensação de termos sido completamente enganados, que somente os grandes autores sabem proporcionar; assim, reparamos que além de sermos testemunhas, somos também vítimas do poder ilusório da literatura, partes envolvidas de uma história da qual pensávamos ser apenas observadores destacados. O fim convencional e previsível, no qual o casal de protagonistas está junto na perspectiva de viver feliz para sempre, esconde a mais traiçoeira e inesperada das ciladas.

\section{OS NÚMEROS NÃO BATEM}

Chico Buarque, assim como Italo Calvino, termina o romance dando a impressão que a história seja concluída, que todos os nós foram desatados e que, no final das contas, os números batem. Mas não é assim. A pista para sair do imbróglio nos levou 
novamente ao centro do labirinto ${ }^{\mathrm{I8}}$. Muitas perguntas ficaram sem respostas. Por exemplo, qual relação liga Budapeste a O Ginógrafo? E O Ginógrafo a O Naufrágio? Quem é exatamente o misterioso “Senhor...”? Kriska foi cúmplice do complô contra José? O Budapeste escrito por José é igual ao Budapeste escrito por Chico? Perguntas que questionam na raiz a função do autor e, sobretudo, desestabilizam a posição do leitor em relação à obra.

Num romance onde nenhum dos autores, reais ou fictícios que se alternam na narrativa, pretendem assumir a autoria da escritura, talvez a única certeza concedida ao leitor é a de que ele também se tornou parte da engrenagem ficcional. Uma solução bizarra, sem dúvida, mas que Borges já incluía entre os direitos basilares do jogo literário, explicando que "se os caracteres de uma ficção podem ser leitores ou espectadores, nós, seus leitores e espectadores, podemos ser fictícios”ํ. E não por acaso Calvino indicava em Borges um dos modelos de ficção que mais o influenciaram na ideação de Se um viajante numa noite de inverno.

Continuando a nossa leitura em paralelo, constatamos que o inusitado desfecho da história foi a questão mais debatida e menos compreendida na época do lançamento do livro do Calvino. Angelo Guglielmi, em uma polêmica resenha publicada em I979 na revista Alfabeta, acusa o escritor italiano de ter concedido ao romance um final lógico e satisfatório, excessivamente banal e decepcionante em relação às premissas, no qual o anseio com que os "os números batem" revelaria uma atitude complacente com os gostos do leitor médio. Em sua resposta, Calvino rebate as colocações de Guglielmi, frisando que o romance é apenas em aparência uma obra fria e calculada pois, na verdade, a escolha da fórmula do final feliz não pretende desvendar o emaranhado de fios que tecem a história, mas, pelo contrário, sublimar ironicamente o seu perdurar:

Obra fechada e calculada, na qual o fechamento e cálculo são apostas paradoxais que apenas indicam a verdade contrária àquela tranquilizadora (de completude e conteúdo) que a própria forma parece significar, isto é, transmitem o sentido de um mundo precário, ao ponto de ruir, despedaçar-se. [...] modelo no qual a primeira regra do jogo é "fazer os números baterem" (ou melhor, fazer parecer que batem quando sabemos que na realidade não batem). Para você, "fazer os números baterem” é apenas uma solução conveniente, ao passo que isso pode muito bem ser visto como exercício acrobático para desafiar, e indicar, o vazio subjacente. [...] Você se escandaliza porque eu "concluo" e pergunta a si mesmo: “Trata-se de uma desatenção de nosso caro amigo?”. Não, pelo

I8 Enquanto a maioria da crítica concentrou a análise no tema do duplo, Caetano Veloso foi um dos poucos a focar a atenção no término sem solução do romance. Em um breve comentário de admirável agudeza sobre Budapeste, salientava que o livro "se resolve, não na trama, mas nas palavras, como a poesia". VELOSO, Caetano. Budapeste é aqui. O Globo, I4 set. 2003.

I9 BORGES, Jorge Luis. Otras inquisiciones. In: Inquisiciones. Otras Inquisiciones. Barcelona: Penguin Random House, 20II, p. I55. Tradução minha. 
contrário: prestei muita atenção e calculei tudo para que o "final feliz" mais tradicional, o casamento do herói com a heroína, selasse a moldura que encerra a desordem geral ${ }^{20}$.

As reflexões de Calvino tornam-se iluminantes para examinar o significado do final feliz de Budapeste. Chico também não pretende dar a impressão de que os números batem. Contudo, a sua conclusão é menos respeitosa e desinteressada em relação à presumida lógica que deveria sustentar o arcabouço do romance. Calvino parece estar mais comprometido com um final que seja convencedor e satisfatório. E, de fato, no penúltimo capítulo ele declara que o núcleo narrativo seria uma história apócrifa das Mil e uma noites, uma espécie de conto arquétipo, matriz de todas as histórias que é possível recompor através da sequência dos títulos (ou incipit) dos dez contos iniciados e nunca terminados:

Se um viajante numa noite de inverno, fora do povoado de Malbork, debruçando-se na borda da costa escarpada, sem temer o vento e a vertigem, olha para baixo onde a sombra se adensa, numa rede de linhas que se entrelaçam, numa rede de linhas que se entrecruzam, no tapete de folhas iluminadas pela lua, ao redor de uma cova vazia-Que história espera seu fim lá embaixo? - ele pergunta, ansioso por ouvir o relato. (S., p. 26I.)

A precisão de tal desenho geométrico não se reencontra em Budapeste. Dispondo em sequência os sete títulos (que nem sempre aqui são incipit) presentes no início de cada capítulo não obteremos um conto, embora os dois primeiros poderiam fazer supor o contrário: "Devia ser proibido, no caso das crianças, eu nunca tinha visto, havia nevascas, grande senhor, ao som de um mar, escrito aquele livro" (B., p. 4, I2, 44, 74, II4, I52 e I66.).

No máximo, os leitores mais audazes recolherão outras dúvidas para acrescentar ao conjunto de perguntas não resolvidas. $\mathrm{O}$ que deveria ser proibido às crianças? $\mathrm{O}$ que as nevascas impediram ver? É ao som do mar do Rio de Janeiro que o livro foi escrito? Qual livro? E o grande senhor terá algum nexo com o misterioso “Sr....”? Uma lógica tampouco parece regulamentar as relações entre os títulos das várias obras literárias espalhadas em Budapeste: "A Madame e o Vernáculo", Inventário Passional, Tercetos Secretos, O Ginógrafo, O Colar de Ameixas, "Interrogar Coelhos”, O Naufrágio, Budapest.

Nesse elenco, as obras de José Costa são somente os Tercetos Secretos e O Ginógrafo (que numa livraria de Copacabana será confundido com O Naufrágio). Intuitivamente esses títulos parecem esconder um anagrama: à primeira vista, secretos pode passar pelo anagrama de tercetos e naufrágio por aquele de ginógrafo. Mas se formos verificar nossas suposições, notaremos que nenhuma delas ganha uma confirmação plena.

\author{
T-E-E- $\underline{R}-\underline{C}-\underline{E}-\underline{T}-\underline{O}-\underline{S}$ \\ S-E-C-R-E-T-O-(S) \\ $\underline{\text { N-A-U}}-\underline{\mathrm{F}}-\underline{\mathrm{R}}-\underline{\underline{A}}-\underline{\mathrm{G}}-\underline{\mathrm{I}}-\underline{\mathrm{O}}$ \\ G-I-N-O-(G)-R-A-F-(O)
}

20 CALVINO, Italo. Se um narrador numa noite de inverno [I979]. In: Se um viajante numa noite de inverno, op. cit., p. 267-268. 
Em ambos os casos faltam poucas letras para compor a palavra por inteiro. Os anagramas são incompletos, e cada palavra reflete parcialmente a outra, assim como a autobiografia de Kaspar Krabbe pode ser lida como uma projeção distorcida da história de José Costa. Em suma, Chico Buarque parece não estar disposto a conceder nenhuma garantia ao leitor. Não satisfeito, pretende alimentar a ilusão de que realmente haja em Budapeste uma lógica escondida capaz de dar coerência e racionalidade a todos os elementos que compõem o enredo. Uma ilusão que é reforçada ainda pelos títulos escolhidos para os poemas que compõem os Tercetos secretos: "Intróito ornítico", "Sinfonia das ninfômanas", "Crepúsculos especulares", "Rapsódia da diáspora", "Apoteose dos poetas".

Mais uma vez, trata-se de anagramas imperfeitos, nos quais a coincidência das letras nunca chega a ser completa:

\section{I-N-T-T-R-O-O-I-T-O \\ $\underline{\text { S}}-\mathrm{I}-\underline{\mathrm{N}}-\underline{\underline{-}}-\underline{\mathrm{O}}-\underline{\mathrm{N}}-\underline{\mathrm{I}}-\underline{\mathrm{A}}-\mathrm{D}-\underline{\mathrm{A}}-\mathrm{S}$ \\ C-R-E-E-P-U-S-S-C-O-L-O- $\underline{S}$ \\ $\underline{\mathrm{R}}-\underline{\mathrm{A}}-\underline{\mathrm{P}}-\underline{\mathrm{S}}-\underline{\mathrm{O}}-\underline{\mathrm{D}}-\underline{\mathrm{I}}-\underline{\mathrm{A}}-\mathrm{DA}$ \\ A-P-D-D-T-E-O- - -E-DOS}

\author{
O-R-N-I-T-I-(C)-O \\ N-I-N-F-O-(M)-A-(N)-A-S \\ E-S-P-(E)-C-U-L-(A)-R-(E)-S \\ DIASPORA \\ POETAS
}

Estamos diante de um jogo de reflexões e refrações cujo mecanismo traiçoeiro parece já estar anunciado pela capa do livro. A quarta capa, inspirada na escritura "de trás para diante" de $O$ Ginógrafo não reproduz, como aparece à primeira vista, a imagem especular do frontispício. Se a pusermos em frente a um espelho, ela revela aos nossos olhos uma imagem diferente daquela que esperávamos. Ainda que o texto publicado corresponda sempre ao mesmo trecho extraído do primeiro capítulo, o nome do autor e do romance mudam. O livro que o espelho reflete não é Budapeste de Chico Buarque, mas Budapest (sem o "e" final), de Zsoze Kósta, e o trecho citado é inexplicavelmente em português e não em húngaro. A história termina, mas a força ficcional da obra transborda para o mundo real, deixando o leitor na dúvida de que o romance intitulado Budapeste de autoria de Chico Buarque tenha sido escrito pelo ghost-writer Zsoze Kósta ou, quem sabe, vice-versa ${ }^{2 \mathrm{~T}}$.

Também em Se um viajante numa noite de inverno, a invenção literária era prenunciada pela capa do livro, em que era reproduzida a pintura Confidences d'une chef de gare, de Dominique Appia ${ }^{22}$ : uma pequena estação ferroviária é contida dentro de uma garrafa de vidro que, por sua vez, está deitada num fundo azul onde a terra confunde-se com o céu. O peculiar estilo onírico do pintor suíço pode ser interpretado como uma tentativa de subverter os confins entre ilusão e realidade em linha com a proposta de Calvino. Com efeito, a estação não pretende ser real, mas é uma peça de modelismo, "como para avisar o leitor de que a imersão no mundo da aventura

\footnotetext{
2I Sobre a questão da autoria em Budapeste, ver a reflexão proposta por Andréia Delmaschio a partir da leitura de Michel Foucault e Roland Barthes. DELMASCHIO, Andréia. op. cit., p. I33-I59.

22 A primeira edição foi lançada em junho de I979 pela editora Einaudi, de Turim, na coleção Supercoralli.
} 
não deverá ser total, pois precisa de atenção e esperteza”²3. Porém, a capa não lança suspeitas sobre a autoria. Ao contrário de Budapeste, o mecanismo de falsificação é baseado numa repetida afirmação da presença do autor. Como foi evidenciado, Se um viajante numa noite de inverno é um livro "duplamente assinado", no qual Calvino coloca o seu nome não somente no frontispício, mas também na primeira e na última frase do romance para lembrar, mais uma vez, que não pode existir autor fictício sem a presença de um autor real ("Você vai começar a ler o novo romance de Italo Calvino, Se um viajante numa noite de inverno", S., p. II; "Estou quase acabando Se um viajante numa noite de inverno, de Italo Calvino”, S., p. 263)24.

$\mathrm{O}$ autoquestionamento da autoria traz de volta o tema do plágio com o qual abrimos estas considerações. Não cabe dúvida de que, para os cobiçosos "caçadores de plagiários", descritos por Marie Darrieussecq, as analogias até aqui evidenciadas entre Budapeste e Se um viajante numa noite de inverno ofereceriam provas irrefutáveis de que Chico Buarque tenha copiado o romance de Italo Calvino. Seria uma dedução previsível, pois a plagiomania é um fenômeno cada vez mais presente na literatura e na sociedade. Chico Buarque escreveu Budapeste sem nunca ter lido Se um viajante numa noite de inverno ${ }^{25}$, mas, afinal de contas, seria uma informação irrelevante, Pois não é ela a determinar a alta qualidade do romance ou a sua interpretação. Dentro daquele labirinto de espelhos que é a literatura, os livros interagem sem a autorização de seus autores. É possível, portanto, que algumas obras revelem fortes semelhanças sem que haja um plágio. E é justamente nessa conversa descontrolada e incontornável entre livros, escritores e leitores, pouco importa se reais ou imaginários, que encontramos o elo mais profundo entre Chico Buarque e Italo Calvino. É nela que ambos apostam, em tempos e de lugares diferentes, para dar voz a angústia do mundo contemporâneo e à incapacidade do homem de relacionar-se com a realidade ao seu redor, até com aquela que lhe deveria ser familiar.

À guisa de conclusão, é oportuno ressaltar como na "inquieta necessidade de clarificação" ${ }^{26}$ que segue o lançamento de Se um viajante numa noite de inverno, o debate entre o escritor e seus críticos é atravessado por uma busca quase obsessiva das fontes. Nas entrevistas e nos artigos, Calvino não pretende defender a originalidade de seu livro, mas, pelo contrário, frisa a repetição de um modelo literário já fartamente desfrutado por outros ilustres predecessores. Com meticulosidade e sem constrangimentos revela suas principais referências (Poe, Borges, Chesterton, Queneau, Roussel, entre outros) e, ao mesmo tempo, assinala que a crítica apontou como fontes de seu romance vários autores nos quais ele nunca tinha pensado. Longe de recusar essas atribuições, Calvino as acolhe com curiosidade, vendo nelas uma ulterior manifestação do misterioso poder da literatura do qual o autor e o leitor são iguais intérpretes e espectadores:

23 FALCETTO, Bruno. Note e notizie sui testi - Se una notte d'inverno un viaggiatore. In: CALVINO, Italo. Romanzi e racconti, vol. 2. Milão: Mondadori, 2004, p. I38I. Tradução minha.

24 Cf. MILANINI, Claudio. Introduzione. In: CALVINO, Italo. Romanzi e racconti, op. cit., p. xxxiv.

25 Em conversas que tive com o autor sobre Budapeste, confirmou conhecer apenas algumas obras de Italo Calvino e nunca ter lido Se um viajante numa noite de inverno.

26 FALCETTO, Bruno. op. cit., p. I388. 
A maioria dos críticos procurou possíveis modelos ou fontes [...] frequentemente emergiram nomes de autores em que eu jamais pensara, o que chama a atenção para um campo pouco explorado até agora: como funcionam as associações mentais entre textos diversos? Por que caminhos um texto é assimilado ou justaposto a outro em nossa mente? ${ }^{27}$

Até quando essas perguntas não receberem uma resposta satisfatória, sempre haverá alguém acusando Pierre Menard de ser um plagiário de Cervantes.

\section{SOBRE O AUTOR}

LUCA BACCHINI é professor assistente de literatura portuguesa e brasileira na Universidade de Bologna, Itália. Email: 1.bacchini@gmail.com

27 CALVINO, Italo. Se um narrador numa noite de inverno, op. cit., p. 266. 


\section{REFERÊNCIAS BIBLIOGRÁFICAS}

ALLEN, Graham. Intertextuality. Londres/Nova York: Routledge, 2000.

ANDRADE, Mário de. Carta a Raimundo Moraes. Publicada no Diário Nacional em 20 de setembro de I93I. In: . Macunaíma. Complemento à edição. Rio de Janeiro: Nova Fronteira, 2015.

ASCHER, Nelson. Chico tem uma história e sabe como contá-la. Folha de S.Paulo, I4 set. 2003.

BERARDINELLI, Alfonso. Calvino moralista, ovvero restare sani dopo la fine del mondo. Diario, n. 7, I99I. BORGES, Jorge Luis. Otras inquisiciones. In: . Inquisiciones. Otras Inquisiciones. Barcelona: Penguin Random House, 20II.

BUARQUE, Chico. Budapeste. São Paulo: Companhia das letras, 2003.

CALVINO, Italo. Se um viajante numa noite de inverno. Trad. Nilson Moulin. São Paulo: Companhia das Letras, 2009.

Se um narrador numa noite de inverno. In: Se um viajante numa noite de inverno. Trad. Nilson

Moulin. São Paulo: Companhia das Letras, 2009.

. Il libro, i libri. Nuovi quaderni italiani, I984. In: Se um viajante numa noite de inverno.

Trad. Nilson Moulin. São Paulo: Companhia das Letras, 2009.

CESERANI, Remo. Raccontare il postmoderno. Turim: Bollati Boringhieri, I997.

CHAGAS, Luís. Estilo retocado. IstoÉ, I7 set. 2003.

COSTA, Caio Túlio. Sobre dessintonias e sintonização. Folha de S.Paulo, Ombudsman, Primeiro Caderno, II ago. I99I.

DARRIEUSSECQ, Marie. Rapport de police. Paris: Folio, 2010.

DELMASCHIO, Andréia. A máquina de escrita (de) Chico Buarque. Rio de Janeiro: 7Letras, 20I4, ECO, Umberto. Postille a "Il nome della rosa". In: . Il nome della rosa. 3. ed. Milão: Bompiani, 2004.

FALCETTO, Bruno. Note e notizie sui testi - Se una notte d'inverno un viaggiatore. In: CALVINO, Italo. Romanzi e racconti, vol. 2. Milão: Mondadori, 2004.

GIGLIUCCI, Roberto. Furto e plagio nella letteratura del classicismo. Roma: Bulzoni, I998.

GIRON, Luís Antônio. Com o diabo na língua. Época, I5 set. 2003.

HOLANDA, Sérgio Buarque de. Plágios e plagiários. In: PRADO, Antonio Arnoni (Org.). O espírito e a letra.

Estudos de crítica literária: vol. I (I920-I947), São Paulo: Companhia das letras, 2005.

MARTINS, Wilson. A imprecisão da literatura de amadores. O Globo, Prosa e Verso, Io fev. I996.

MASCHERONI, Luigi. Elogio del plagio. Storia, tra scandali e processi, della sottile arte di copiare da Marziale al web. Turim: Aragno, 2015.

MILANINI, Claudio. Introduzione. In: CALVINO, Italo. Romanzi e racconti, vol. 2. Milão: Mondadori, 2004. PAVLOVA, Adriana; SUKMAN, Hugo. Ataque a amadorismo na literatura divide escritores. O Globo,

Segundo Caderno, I3 fev. I996.

POSNER, Richard. The Little Book of Plagiarism. Nova York: Pantheon Books, 2007.

RESENDE, Beatriz. Livro dentro de livro. Jornal do Brasil, I4 set. 2003.

SCHWARCZ, Luiz. O leitor é um amador por natureza, O Globo, Prosa e Verso, I7 fev. I996.

SONNINO, Maurizio. L'accusa di plagio nella commedia attica antica. In: MASCHERONI, Luigi. Elogio del plagio. Storia, tra scandali e processi, della sottile arte di copiare da Marziale al web. Turim: Aragno, 20I5.

VELOSO, Caetano. Budapeste é aqui. O Globo, I4 set. 2003.

WISNIK, José Miguel. Novo romance de Chico Buarque. O Globo, I4 set. 2003. 